10.15290/cnisk.2019.02.07.04

DR ŁUKASZ JĘDRZEJSKI

orcid.org/0000-0002-2632-9117

Uniwersytet Marii Curie-Skłodowskiej w Lublinie

\title{
Obraz wyborów do Sejmu Polskiej Rzeczypospolitej Ludowej w 1957 r. w publicystyce „Kobiety i Życia”
}

\section{Streszczenie}

Celem artykułu jest przedstawienie komunikacyjnych wizji wyborów do Sejmu Polskiej Rzeczypospolitej Ludowej w 1957 r. na łamach ważnego kanału treści społecznych i politycznych, jakim był periodyk „Kobieta i Życie”. Uwagę badawczą skupiono na następujacych kwestiach: (1) Jakie specyficzne cechy miał profil prasowy badanego periodyku? (2) Jakie specyficzne idiolekty językowe i słowa sztandarowe występowały w przekazie prasowym w trakcie kampanii wyborczej do Sejmu PRL na przełomie 1956/1957 r.? (3) Jakie formy gatunkowe dominowały $\mathrm{w}$ formułowanym przekazie prasowym?

Słowa kluczowe: Polska Zjednoczona Partia Robotnicza, prasa polityczna, kobiety, wybory, Władysław Gomułka

\section{THE IMAGE OF THE 1957 ELECTION TO THE POLISH PEOPLE'S REPUBLIC SEJM IN THE JOURNALISM OF “KOBIETA I ŻYCIE"}

\begin{abstract}
The purpose of the article is to present the communicative image of the elections to the Sejm of the Polish People's Republic in 1957 in the important channel of social and political content of the "Kobieta i Życie" [Woman and Life] journal. It was worth focusing the research attention on the following issues: (1) What specific features did the press profile of the
\end{abstract}


periodical in question have? (2) What specific language idiolects and banner words were present in the press during the election campaign to the Sejm of the Polish People's Republic at the turn of 1956/1957? (3) What genre forms dominated in press releases?

Keywords: Polish United Worker's Party, political press, women, election, Władysław Gomułka

\section{Uwagi wstępne}

W XIX-wiecznej Europie wykształcił się model systemu politycznego nazywanego parlamentaryzmem. Jedna $z$ konstytutywnych cech demokracji parlamentarnej jest m.in. występowanie zróżnicowanych pod względem prezentowanej myśli politycznej partii politycznych. Ważnym elementem systemów demokratycznych stał się system wyborczy obejmujący możliwość wybierania przez społeczeństwo swoich przedstawicieli do organów kolegialnych państwa ${ }^{1}$. Istnienie w systemach politycznych prawa wyborczego stało się kanonem obowiazującym na całym świecie. W państwach niedemokratycznych akt wyborczy ma charakter plebiscytarny, poprzedza go, podobnie jak w przypadku państw demokratycznych, kampania wyborcza. W państwach niedemokratycznych wyniki wyborów sa zazwyczaj ustalone na wcześniejszym etapie. Dlatego we wstępie niniejszego artykułu za zasadne uznano ustosunkowanie się do sformułowanego tematu prowadzonych rozważań.

W Polsce Ludowej i w Polskiej Rzeczypospolitej Ludowej akt wyborów miał specyficzny charakter, na co wpływało ideowo-polityczne oblicze ówczesnej rzeczywistości politycznej. Na gruncie politologicznym główna cechą wyborów jest możliwość prezentacji autentycznie konkurencyjnych programów, wizji i koncepcji wcielanych w życie przez rywalizujące, odmienne siły polityczne. Gdy w systemie politycznym w państwie nie występuja przeciwstawne stronnictwa polityczne, które maja alternatywne programy, i gdy nie ma realnej możliwości dokonania selekcji wśród kandydatów ubiegajacych się o mandat w parlamencie, a liczba kandydatów jest równa liczbie miejsc do obsadzenia w parlamencie, wówczas nie można pisać o formie demokratycznych wyborów ${ }^{2}$. Mimo tych dylematów

1 Andrzej Antoszewski, Współczesne teorie demokracji, (Warszawa : Wydawnictwo Sejmowe, 2016), 5-17.

2 Jerzy Eisler, „Wybory w PRL: wprowadzenie do zagadnienia”, w: Sebastian Ligarski, Michał Siedziako (red.), Wybory i referenda w PRL, (Szczecin : Instytut Pamięci Narodowej, 2014), 17. 
w siatce pojęciowej zawartej w tekście świadomie zdecydowano się na używanie słowa „wybory” dla lepszego opisania sytuacji społeczno-politycznej majacej miejsce w PRL na przełomie 1956/1957 r. Taka decyzja spowodowana była wyjątkowym charakterem wyborów ze stycznia 1957 r., na które wpłynęły następujące czynniki. Po pierwsze, zmieniająca się atmosfera polityczna w państwie spowodowana wydarzeniami nazywanymi w literaturze przedmiotu polskim Październikiem. Po drugie, wprowadzona zmiana ordynacji wyborczej w wyborach do sejmu PRL.

Celem niniejszego artykułu jest przedstawienie formułowanych przez władze państwowe komunikacyjnych obrazów przebiegu wyborów do sejmu PRL przypadających na 20 stycznia 1957 r., na łamach ważnego kanału treści społecznych i politycznych, jakim było czasopismo „Kobieta i Życie”. Problematyka dotyczacca funkcjonowania prasy dla kobiet we współcześnie prowadzonych badaniach prasoznawczych jest dość dobrze spenetrowana, gdyż podejmowali ją liczni badacze: historycy, politolodzy, socjologowie, medioznawcy ${ }^{3}$. Istotnym dorobkiem w tym zakresie może się poszczycić Zofia Sokól $1^{4}$. Tego rodzaju badania $z$ powodzeniem realizują badaczki skupione w ośrodku w Białymstoku ${ }^{5}$. Małgorzata Dajnowicz jest założycielką i prezesem stowarzyszenia Instytut Studiów Kobiecych, afiliowanego przy Uniwersytecie w Białymstoku' ${ }^{6}$.

\footnotetext{
3 Zbigniew Bajka, Czytelnictwo prasy $w$ Polsce w 1986 roku, (Kraków : RSW Prasa-Ksiażka-Ruch, 1987), passim; Ryszard Kalbarczyk, „Kto czyta pismo kobiece?”, Nasze Problemy, t. 3, 1979, 35-40; Anna Maliszewska, „Wzory wychowawcze w prasie kobiecej (szkoła i rodzina jako instytucje wychowawcze)”, Zeszyty Prasoznawcze, t. 4, 1975, 15-25; Franciszek Adamski, Modele małżeństwa i rodziny a kultura masowa, (Warszawa : PWN, 1970), passim; Idem, „Konflikty małżeńskie i ich źródła na łamach "Kobiety i Życia»”, Zeszyty Prasoznawcze, t. 1, 1978, 23-32; Krystyna Konarska, Maria Łoś, Małgorzata Łoskot, „Czasopisma kobiece czy rodzinne?”, Więź, t. 9, 1965, 55-73; Sabina Szczepańska, „Kobieta - zwierzę polityczne?”, w: Małgorzata Radkiewicz (red.), Gender - kultura - społeczeństwo, (Kraków : Wydawnictwo Rabit, 2002), 91-100.

4 Zofia Sokół, „Transformacja czasopism kobiecych w Polsce (1989-1997)”, Rocznik Historii Prasy Polskiej, t. 1, 1998, 193-201; Eadem, „Wzór osobowy kobiety i model rodziny propagowany na łamach prasy kobiecej w latach 1945-1990", w: Weronika Chańska, Danuta Ulicka (red.), Polskie oblicza feminizmu, (Warszawa : Wydawnictwo Uniwersytetu Warszawskiego, 2000), 66-85.

5 Małgorzata Dajnowicz, Adam Miodowski (red.), Polityka i politycy $w$ prasie XX i XXI wieku, (Białystok : Wydawnictwo Humanica, 2016), passim; Małgorzata Dajnowicz, Adam Miodowski (red.), Polityka i politycy $w$ prasie XX i XXI wieku. Prasa organizacji politycznych, (Białystok: Wydawnictwo Humanica, 2017), passim; Małgorzata Dajnowicz, Adam Miodowski (red.), Polityka i politycy $w$ prasie XX $i$ XXI wieku. Polityka $w$ prasie kobiecej, (Białystok : Wydawnictwo Uniwersytetu w Białymstoku, 2019), passim.

6 Stowarzyszenie Instytut Studiów Kobiecych, [Dostęp: 9.09.2019]. Dostępny w World Wide Web: <http://www.isk. bialystok.pl/>.
} 
Cezura czasowa przyjęta do prezentacji obrazów wyborów do sejmu obejmowała przełom lat 1956-1957, determinowało ją oficjalne rozpoczęcie kampanii wyborczej, która zakończył akt głosowania zaplanowany na 20 stycznia $1957 \mathrm{r}$. Uwagę badawczą skupiono na następujacych kwestiach: Jakie specyficzne cechy miał profil prasowy periodyku? Jakie specyficzne idiolekty językowe i słowa sztandarowe występowały w przekazie prasowym w trakcie kampanii wyborczej do sejmu PRL na przełomie 1956/1957 r.? Jakie formy gatunkowe dominowały w formułowanym przekazie prasowym? Artykuł ma strukturę problemowa $z$ zachowaniem przyjętych ram temporalnych. Składa się ze wstępu, części poświęconej rozważaniom merytorycznym i zakończenia dopełnionego sformułowanymi wnioskami.

Dobór i obsługa narzędzi pomiarowych, użytecznych dla sporządzenia artykułu, były zdeterminowane charakterem politologii i jej badań zjawisk i procesów politycznych. Przedmiotem eksploracji były komunikaty polityczne rozumiane jako specyficzne ogłoszenia zawierajace informacje lub kształtujące postawy i dające możliwość wykorzystania zasobów ludzkich in gremio bądź indywidualnych jednostek ludzkich, wprowadzenia rozwiazań systemowych w sferze polityki, wykonywania czy delegowania obowiązów, a także realizowania praw człowieka i obywatela, wpływania na instytucje i ludzi angażujących się w życie polityczne. Ujęcie idiograficzne pozwoliło ukazać uszczegółowiony obraz świata politycznego. Wprawdzie zawiera ono sfragmentaryzowaną wiedzę, ale o charakterze funkcjonalnym, umożliwiając powiązanie efektów opisu obserwacji $z$ wartościowaniem zjawisk i procesów politycznych ${ }^{7}$.

Przed rozpoczęciem badań skonstruowana została lista kodów tematycznych, użyteczna przy późniejszym ustalaniu swego rodzaju paralelnego zestawienia zagadnień, z których tworzył się szkielet opracowania. Selekcjonując odpowiednie słowa klucze ${ }^{8}$, częściowo oparto się na istniejących już zestawach kategorii politologicznych, znanych $z$ literatury przedmiotu, co dało podstawę do ustalenia wiedzy o preferencjach

\footnotetext{
7 Zbigniew Kantyka, „Politologia (I)”, w: Wojciech Sokół, Marek Żmigrodzki (red.), Encyklopedia politologii, t. 1: Pojeccia, teorie i metody, (Warszawa : Wydawnictwo Wolters Kluwer, 2016), 481.

8 Formułowane przez polityków słowa klucze obecne na łamach prasy nierzadko przybierały formę skrzydlatych słów, czyli takich, które sa często przytaczane i rozpowszechniane, a ich autorstwo jest na ogół znane. Pod względem formalnym pod tym pojęciem występuja najczęściej zwiąki wyrazowe, a więc słowa o charakterze nominalnym. Henryk Markiewicz, Andrzej Romanowski, Skrzydlate słowa, (Warszawa : Wydawnictwo PWN, 1990), 6-7.
} 
komunikowania politycznego w prezentowanym okresie PRL. Na liście znalazły się główne kody, takie jak: ideologia, życie polityczne, wybory, ordynacja wyborcza, demokratyzacja, udział kobiet w wyborach i w obradach sejmu. Takie postępowanie było niezbędne podczas wstępnej analizy zebranego materiału na etapie eksplorowania źródeł, a następnie interpretowania dokumentacji. Okazało się też korzystne dla finalnego redagowania tekstu, szczególnie podczas sprawdzania jego stopnia logiczności i przejrzystości treści.

Podczas sporządzania artykułu użyteczna była metoda analizy systemowej. Dzięki niej periodyk „Kobieta i Życie” rozpatrywano jako instytucję polityczna stanowiąca element systemu propagandowego PRL. W tekście zastosowano technikę analizy zawartości mediów, która dotyczyła propagandowej treści komunikatów politycznych formułowanych przez partyjnych decydentów i zespół redakcyjny „Kobiety i Życia”. Szczególną uwage zwrócono na frekwencyjność występujących w komunikatach słów sztandarowych, stanowiących elementy specyficznego metajęzyka używanego przez twórców komunikowania politycznego periodyku. Słowa te odnosiły się zazwyczaj do określenia panującej w państwie ideologii mającej wszechogarniajacy charakter i obowiąującego w popaździernikowej Polsce sposobu formułowania dyskursu politycznego. Stanowiły również nośne hasła propagandowe formułowane przez partyjnych decydentów, a odnoszące się do życia politycznego, społecznego. Technika była spożytkowana, aby scharakteryzować specyficzne idiolekty językowe zawarte w przekazie komunikacyjnym do opisu propagandowego obrazu rzeczywistości politycznej i społecznej. Kryterium klasyfikacyjnym analizy były przekazy słowne formułowane w komunikatach redakcyjnych. Medialna analiza treści zawartych w „Kobiecie i Życiu” realizowana była na podstawie słownych wypowiedzi dziennikarzy, działaczek społecznych i partyjnych decydentów, utrwalonych w zapisie prasowym ${ }^{9}$.

Przy sporządzaniu artykułu wykorzystano głównie artykuły prasowe zamieszczane na łamach periodyku. Dla dopełnienia wywodu spo-

9 Walery Pisarek, Wstęp do nauki o komunikowaniu, (Warszawa : Wydawnictwa Akademickie i Profesjonalne, 2008), 245-249; Idem, O mediach i języku, (Kraków : Wydawnictwo Universitas, 2007), 47-63; Małgorzata Lisowska-Magdziarz, Analiza tekstu $w$ dyskursie medialnym, (Kraków : Wydawnictwo Uniwersytetu Jagiellońskiego, 2006), passim. 
żytkowano szereg opracowań naukowych z zakresu nauk o polityce, nauk o komunikacji społecznej i mediach.

\section{Profil prasowy periodyku}

Czasopismo „Kobieta i Życie” powstało z połączenia wydawanej przez spółdzielnię „Czytelnik” dekady pt. „Moda i Życie Praktyczne” z miesięcznikiem „Kobieta”, który został przejęty od Zarządu Głównego Ligi Kobiet w 1951 r. Robotnicza Spółdzielnia Wydawnicza „Prasa” zaczęła wydawać periodyk pt. „Kobieta i Życie Praktyczne”. W 1953 r. nastapiła modyfikacja tytułu czasopisma i na rynku wydawniczym zaczał się pojawiać periodyk pt. „Kobieta i Życie”. Ze zmianą tytułu wiązała się również zmiana dotychczas realizowanego przez redakcje programu prasowego. Od tego momentu pismo pełniło funkcję polityczno-społeczna. Adresatkami prezentowanych w nim treści były zazwyczaj kobiety lepiej wykształcone niż czytelniczki „Przyjaciółki”. Do 1956 r. w przekazach prasowych widoczna była wyraźna trudność $z$ identyfikacją adresatek komunikatów politycznych. Były to m.in.: przodownice pracy, nauczycielki, urzędniczki, działaczki społeczne zrzeszone najczęściej w Lidze Kobiet lub członkinie $\mathrm{PZPR}^{10}$. Penetrując dzieje pisma, należało wyszczególnić kilka umownych okresów w jego funkcjonowaniu: lata 1951-1956 (powstanie pisma pod tym tytułem - wydarzenia października 1956), 1957-1981 (wybory do sejmu PRL z 20 stycznia - wprowadzenie stanu wojennego), 1982-1990 (schyłek PRL i początek formułowania się zrębów III Rzeczypospolitej), 1990-2002 - funkcjonowanie czasopisma w III RP. Nie wydaje się zasadne rozpatrywanie wszystkich przywołanych okresów ${ }^{11}$.

$\mathrm{W}$ analizowanym przedziale czasowym na stanowisku redaktora naczelnego Henryka Butkiewicza zastapiła Jadwiga Baranowska. Wydarzenia $z$ lat 1953-1956 - „odwilż” polityczna w Związu Socjalistycznych Republik Radzieckich spowodowana śmiercią Józefa Stalina i przełom październikowy w PRL przypadajacy na 1956 r. ${ }^{12}$ - spowodowały, iż dostrzeżono zawodowe zróżnicowanie kobiet: inteligentki pracujące, kobiety

10 Zofia Sokół, Prasa kobieca $w$ Polsce $w$ latach 1944-1995, (Rzeszów : Wydawnictwo Wyższej Szkoły Humanistycznej, 1998), 104.

11 Eadem, „Kobieta i Życie (1946-2002)”, Studia Bibliologiczne Akademii Świętokrzyskiej, t. 9, 2005, 69 .

12 Eadem, „Wizerunki kobiet na łamach tygodnika "Kobieta i Życie» w latach 1946-2002”, Rocznik Prasoznawczy, t. 6, 2012, 17-18. 
z wykształceniem średnim ogólnym i zawodowym oraz kobiety proste $z$ wykształceniem podstawowym. Po przełomie październikowym widoczne było wyraźne rozszerzenie oferty tytułów prasowych adresowanych do kobiet ${ }^{13}$. Ówcześni dziennikarze podejmowali starania o uzyskanie jak największej autonomii w formowaniu linii redakcyjnej czasopism, doborze najlepszych treści i tematów poruszanych na łamach prasy ${ }^{14}$.

Nie inaczej było w przypadku „Kobiety i Życia” . W 1956 r. na łamach czasopisma dominowały odniesienia do uchwalonej przez organy państwa 27 kwietnia $1956 \mathrm{r}$. Ustawy o warunkach przerywania ciąży. Redakcja periodyku, wychodząc naprzeciw prośbom czytelniczek zawartych $\mathrm{w}$ ankietach prasowych i nadsyłanych listach, poruszała tematy dotąd uważane za tabu. Czasopismo stało się organem prasowym propagującym idee świadomego macierzyństwa i edukacji seksualnej ${ }^{15}$. Na jego łamach problematyka zwiazana ze sprawami politycznymi znajdowała się zawsze na drugiej i trzeciej stronie. Takie umiejscowienie przekazów politycznych świadczyło, że kwestie polityczne stanowiły ważny element konstruowanego przekazu medialnego. W czasopiśmie dominowały przedruki dokumentów państwowych odnoszacych się do wyborów, przedruki przemówień partyjnych decydentów czy instrukcje partyjne. Jak wspomniano, tematy o charakterze politycznym umieszczano na stronie numer 2. Był to stały element pozycjonowania ważnych treści politycznych nazywanych w literaturze przedmiotu agenda-setting.

Ważną rolę odgrywała w tym konsekwentnie stosowana tematyzacja opinii publicznej. Według ustaleń poczynionych przez Niklasa Luchmanna media masowe odgrywaja decydujaca rolę w wyznaczaniu tematów, które stają się istotne dla odbioru przez opinię publiczna pre-

13 Po przełomie październikowym na rynku wydawniczym zaczęły się pojawiać m.in.: „Filipinka”, „Gospodyni”, „Gospodarstwo Domowe”, „Ja i Mój Dom”, „Pielęgniarka i Położna”, „Zwierciadło”.

${ }_{14}$ Dobrym przykładem takiego postępowania był zamieszczony na łamach „Kobiety i Życia” przedruk $z$ „Życia Warszawy” odezwy autorstwa pisarza, poety, publicysty i polityka ówcześnie rządzącej partii Jerzego Putramenta pt. Nie zmarnujcie tej szansy. Putrament pisał, jaką rolę powinna odegrać ówczesna prasa w „oczyszczeniu” dyskursu prasowego $z$ ideologicznych miazmatów okresu stalinizmu. Twierdził m.in.: „Pionierska rola prasy w oczyszczaniu socjalizmu ze wszystkich chorób ery stalinowskiej nie jest przypadkowa. Tylko przyjmując jej prawo głosu, prawo inicjatywy politycznej, prawo i obowiazek nie uzgadnianej z "aparatem" krytyki tegoż aparatu - możemy liczyć na jej pomoc w budownictwie socjalizmu. Tylko wtedy ona będzie szanowana w społeczeństwie, to znaczy - tylko wtedy jej inspiracja polityczna będzie docierała do dusz ludzkich”, Jerzy Putrament, „Nie zmarnujcie tej szansy", Kobieta i Życie, nr 2, 1956, 2.

15 Zofia Sokół, „Kobieta i Życie”, 73-75. 
zentowanych treści. W odniesieniu do tematu zwiazanego $z$ wyborami na łamach periodyku występowały cztery etapy „kariery tematu”: uśpienia, przełomu, popularności i wyczerpania ${ }^{16}$.

\section{Przebieg kampanii wyborczej}

W atmosferze popaździernikowej najważniejszą sprawą dla nowego kierownictwa partii było przeprowadzenie zwycięskich wyborów do sejmu. Było to ważne jeszcze $z$ jednego powodu. Mianowicie upłynęła już czteroletnia kadencja sejmu wybranego 26 października 1952 r. ${ }^{17}$ Do przełomu październikowego data wyborów planowana była na 16 grudnia 1956 r. Ze względu jednak na niepewne nastroje społeczne zdecydowano się ja przesunać na 20 stycznia 1957 r. Na łamach „Kobiety i Życia” pojawiło się obwieszczenie informujące o planowanych wyborach i zmianie ordynacji wyborczej. Informowano: „Przedstawienie projektu zapowiedziała Polska Zjednoczona Partia Robotnicza, ustami członka Biura Politycznego - Romana Zambrowskiego" ${ }^{18}$. Zmiana ustawodawstwa wyborczego planowana przez Biuro Polityczne PZPR zwiazana była $z$ demokratyzacja.

To pojęcie - demokratyzacja - wystapiło w powyższym tekście trzy razy, stajac się w ten sposób słowem sztandarowym. Zdominowało ono ówczesny dyskurs polityczny, a według medioznawcy i językoznawcy Walerego Pisarka było wyrazem lub wyrażeniem, które $z$ racji swej wartości denotacyjnej albo konotacyjnej czy emotywnej nadawało się na sztandary i transparenty. Demokratyzacja jako słowo sztandarowe bądź nazywane inaczej pojęciem flagowym, wyrazem ważnym, symbolem politycznym czy megasłowem, w założeniu twórców komunikowania politycznego miało być nacechowane dodatnio i wśród odbiorców komunikatów wywoływać pozytywne emocje, czyli tzw. mirandy ${ }^{19}$.

\footnotetext{
16 Niklas Luhmann, „Öffentliche Meinung”, Politische Vierteljahresschrift, vol. 11, 1975, 2-28; Ewa Nowak, „Teoria agenda-setting a nowe media”, Studia Medioznawcze, $\mathrm{nr} 3$, 2016, 11-13.

17 Jerzy Eisler, Czterdzieści pięć lat, które wstrzasnęły Polską. Historia polityczna PRL, (Warszawa : Wydawnictwo Czerwone i Czarne, 2018), 198-199.

18 „Krótko o ważnych sprawach - w kraju”, Kobieta i Życie, nr 29, 1956, 2.

19 Walery Pisarek, Polskie słowa sztandarowe i ich publiczność, (Kraków : Wydawnictwo Universitas, 2002), 7.
} 
W odniesieniu do zmian ordynacji wyborczej w nadchodzących wyborach na łamach periodyku często pojawiały się relacje $z$ prac komisji sejmowych. Pisano: „Sejmowa komisja pracuje nad zmianami w ordynacji wyborczej. Zmiany te maja pójść w kierunku demokratyzacji aktu wyborczego" ${ }^{20}$. W komunikacie politycznym występowały również słowa sztandarowe odnoszace się do deklaratywnego "demokratycznego" charakteru wyborów, były to m.in.: „niepodległość (1 raz), niezawisłość (1 raz), demokratyzacja (1 raz)"21. Przywołany artykuł miał cechy przynależne relacji, jak np. opis zdarzenia, które jeszcze się nie zakończyło, występowała równowaga równoczesna, czyli narastanie w relacjonowaniu poszczególnych faz zdarzenia. Przywołane słowa sztandarowe miały również za zadanie „ubarwić” opisywaną sytuację 22 .

Przebieg wyborów w 1957 r. nierozerwalnie był zwiąany $z$ wprowadzeniem nowej ordynacji wyborczej. Na łamach „Kobiety i Życia” kwestie związane $z$ objaśnianiem jej zawiłości zajmowały ważne miejsce w agendzie medialnej. Jej wprowadzenie łączono $z$ dojrzała postawą społeczeństwa w okresie Października i w założeniu partyjnych decydentów miało być nagrodą za zdany „egzamin dojrzałości” obywatelskiej. Pisano: „W październikowych dniach naród polski zdał celująco egzamin dojrzałości politycznej. Nigdy chyba nie był jeszcze tak jednomyślny. ... W październikowych dniach spadła maska obłudy i wstecznictwa"23.

20 „Wkrótce wybory”, Kobieta i Życie, nr 30, 1956, 2.

${ }^{21}$ Ibidem. Słowa sztandarowe odgrywały dużą rolę przy formułowaniu agendy-setting. Przy nacechowaniu słów ładunkami pozytywnymi i negatywnymi ważną rolę odgrywają tzw. atrybuty, czyli cechy przynależne osobom, sytuacjom politycznym, wydarzeniom. Podczas ustanawiania agendy wyróżnia się dwa rodzaje atrybutów: o charakterze substancjalnym i afektywnym. Atrybuty substancjalne odnoszą się do konkretnych cech, kwestii lub aktora politycznego, afektywne zaś do pozytywnej, negatywnej lub neutralnej oceny atrybutów substancjalnych. Ewa Nowak, Ustanawianie agendy politycznej przez media. Efekt newsa w Polsce, (Lublin : Wydawnictwo Uniwersytetu Marii Curie-Skłodowskiej, 2014), 52-53.

${ }^{22}$ Kazimierz Wolny-Zmorzyński, Andrzej Kaliszewski, Wojciech Furman, Gatunki dziennikarskie. Teoria, praktyka, język, (Warszawa : Wydawnictwo WSIP, 2006), 43.

${ }^{23}$ Anna Wolf, „W Sejmie”, Kobieta i Życie, nr 32, 1956, 3. Leksemy zawarte w artykule nacechowane były ładunkiem ideologicznym. Zideologizowanie tekstu miało wpływać na postawy społeczne, które w założeniu partyjnych decydentów miały się układać w jeden spójny wzór zachowań akceptowalny przez władze państwowe. Komuniści zawsze łączyli działania ideologiczne $z$ postawami społecznymi, ideologia była zatem determinowana na podstawie funkcjonowania społeczeństwa, a nie była czymś odrębnym czy od niego oderwanym. John Fiske, Wprowadzenie do badań nad komunikowaniem, (Wrocław : Wydawnictwo Uniwersytetu we Wrocławiu, 1999), 206-207. 
W artykule prasowym wyjaśniono podstawowe założenia nowego ustawodawstwa wyborczego. Zwracano uwagę na deklaratywna powszechność, równość, bezpośredniość i tajność wyborów. Redakcja periodyku $z$ satysfakcją przyjmowała rozwiązania mające na celu zwiększenie liczby okręgów wyborczych i zmniejszenie ich zasięgu terytorialnego. $\mathrm{Z}$ zadowoleniem odnoszono się do propozycji wzrostu liczby kandydatów w stosunku do liczby mandatów poselskich do obsadzenia przypadajacych na dany okręg wyborczy ${ }^{24}$. Podobnie jak w poprzednich artykułach, w przekazie komunikacyjnym dominowały słowa sztandarowe zwiazane $z$ demokratycznym charakterem państwa, takie jak: demokratyczny (1 raz), głosowanie (1 raz), wybór (1 raz), wybory (1 raz), demokratyzacja (4 razy). Pod względem gatunkowym prezentowany fragment artykułu miał wszelkie cechy charakterystyczne dla sprawozdania. Zostało zaprezentowane zdarzenie o wyjątkowym charakterze, jakim było ostatnie posiedzenie sejmu wybranego w $1952 \mathrm{r}$. Fakty przedstawione w artykule cechowały się dynamicznościa, były osadzone w porządku czasowym. Publicystka starała się wiernie zachować obowiąujące chronologiczne następstwo zdarzeń w trakcie sesji sejmu. Nie dokonano również całościowego przedstawienia polityków zabierajacych głos w trakcie obrad. Zdecydowano się tylko na podanie imion i nazwisk posłów, ewentualnie pełnionych przez nich funkcji w aparacie państwowym, jak miało to miejsce w przypadku premiera Józefa Cyrankiewicza. Cechą charakterystyczna prezentowanego fragmentu artykułu było przywołanie wypowiedzi postaci w formie in extenso lub streszczeńn ${ }^{25}$.

Zamieszczone w nowej ordynacji wyborczej rozwiąania uwidaczniały fasadowość planowanego głosowania i dążenie partyjnych decydentów do $z$ góry przesądzonego, korzystnego dla elity partyjnej wyniku wyborczego. Świadczył o tym choćby zapis stanowiący o tym, że wyborcy mogli głosować, dokonując skreśleń na liście wyborczej. Jeśli pozostała ona bez skreśleń, głos uważany był za ważny. Jeśli nie rozważymy sytuacji mało prawdopodobnej, czyli dużej liczby skreśleń, takie przygotowanie list niemal $z$ góry gwarantowało osobom umieszczonym na czołowych miejscach zdobycie mandatów poselskich ${ }^{26}$.

\footnotetext{
24 Ibidem.

${ }^{25}$ Kazimierz Wolny-Zmorzyński, Andrzej Kaliszewski, Wojciech Furman, Gatunki dziennikarskie, 43.

26 Pierre Buhler, Anatomia oszustwa. Polska w czasach komunizmu, (Warszawa: Wydawnictwo Narodowego Centrum Kultury, 2014), 327.
} 
W czasie kampanii wyborczej w szeregach partyjnych panowało tzw. rozprężenie partyjne. Spowodowane to było niemożnością odnalezienia się przez członków PZPR w nowych warunkach politycznych, jakie nastały w PRL między październikiem 1956 a styczniem 1957 r. W omawianym okresie widoczne były próby podważania dyscypliny partyjnej. Zjawisko „rozprężenia” zaobserwowano także w organizacjach masowych, które nie brały praktycznie większego udziału w kampanii wyborczej. Prawie żadnej istotnej roli nie odegrała wówczas Samopomoc Chłopska. Również zwiazki zawodowe nie angażowały się w działania kampanijne. Nieco inaczej zaś wyglądała działalność Ligi Kobiet, której członkinie popierały kandydatów wystawionych na listach Frontu Jedności Narodu ${ }^{27}$.

Działania popularyzatorskie skupiały się głównie na przedstawieniu sylwetek kobiet znajdujących się na listach. Podejmowano też próbę nakreślenia najważniejszych $z$ punktu widzenia kobiet kwestii o charakterze społecznym, które powinny być podjęte przez przyszły sejm. O zaangażowaniu się w kampanię struktur Ligi Kobiet świadczył fakt, że na łamach „Kobiety i Życia” znalazł się przedruk listu otwartego autorstwa przewodniczaccej Zarządu Głównego Ligi Kobiet Alicji Musiałowej. Działaczka polityczna potwierdziła w nim poparcie udzielone przez Ligę Kobiet dla programu politycznego FJN. Określiła także podstawowe zadanie, jakie według Ligi powinien spełniać przyszły Sejm: „Główne zadanie nowego Sejmu [Liga] widzi w śmiałym zerwaniu ze wszystkim co stare i złe w naszym życiu i w ukształtowaniu nowego, odpowiadającego ludzkim potrzebom i uczuciom polskiego modelu socjalizmu"28.

Ważnymi zagadnieniami poruszanymi przez Musiałową w liście były $m$.in. polityka zatrudnienia kobiet, system wsparcia socjalnego, poprawa sytuacji kobiet w wieku emerytalnym ${ }^{29}$. Przytoczony tekst miał wiele cech charakterystycznych dla listu otwartego. Sformułowanie tematu zawierało samo w sobie prezentacje problemu kierowanego do szerszego grona odbiorców. Ponadto został jasno przedstawiony problem, z jakim zwracał się nadawca do potencjalnego odbiorcy. Musiałowa opisała również problemy i podała argumenty mające pomóc w ich rozwiązaniu.

27 Joanna Olejniczak, Wybory do Sejmu i rad narodowych $w$ okresie rzadów Władysława Gomulki, w: Wybory i referenda w PRL, 156-157.

${ }_{28}$ Alicja Musiałówna, „Czego oczekujemy od Sejmu”, Kobieta i Życie, nr 75, 1956, 2.

29 Ibidem. 
Listy wyborcze zostały ogłoszone stosunkowo późno, bo dopiero 16 grudnia 1956 r., o czym poinformowano na łamach „Kobiety i Życia”. O nowym otwarciu i wyjątkowości wyborów miała świadczyć deklaratywna, staranna selekcja kandydatów na posłów. Redakcja periodyku informowała, że większość kandydatów to ludzie, którzy nie brali udziału w pracach poprzedniego sejmu. „Część $z$ nich była w minionym okresie odsunięta od czynnego życia politycznego"30. Przywołana wzmianka cechowała się seryjnym charakterem treści. Cały ich zbiór został opatrzony odrębna rama tekstowa, będacej tytułem serii wzmianek. Cechowały się one luźnym układem kompozycyjnym, a wzorzec kanoniczny miał spetryfikowaną strukturę składającą się $z$ tytułu i korpusu głównego ${ }^{31}$.

Pod względem leksykalnym przytoczony komunikat wyraźnie zaznaczał, że wybory były kontynuacją zapoczątkowanego przez Gomułkę w październiku 1956 r. odrzucenia i potępienia stalinizmu. Pojawienie się na listach wyborczych ludzi niezwiazanych $z$ poprzednim represyjnym systemem stalinowskim świadczyło o kontynuacji odejścia od niego. Retoryka przedwyborcza prezentowana w artykułach prasowych pozwalała sądzić, że nastapi dalsze odejście od atmosfery strachu przy deklaratywnej niezależności od władz w Moskwie i proponowanej małej stabilizacji niosącej ze sobą poprawę sytuacji społecznej metodą małych kroków ${ }^{32}$.

W styczniu 1957 r. na łamach „Kobiety i Życia” znów pojawiła się odezwa do kobiet sygnowana przez Zarząd Główny Ligi Kobiet, który sformułował zadania stojące przed organizacja. Do najważniejszych kwestii ówczesnego okresu zaliczano walkę o praworząność, pełna demokratyzację, poszanowanie swobód konstytucyjnych, słuszna politykę gospodarcza ${ }^{33}$. W przekazie komunikacyjnym wyjaśniono, jak należało rozumieć przytoczone w tekście idiolekty językowe: „Słowa te oznaczają, że nie powtórza się wypadki krzywdzenia człowieka, że przywrócone zostanie w pełni poszanowanie godności ludzkiej. Że ludzie będą żyć i pracować spokojnie" ${ }^{34}$.

30 „Krótko o ważnych sprawach. W Kraju”, Kobieta i Życie, nr 1, 1957, 2.

31 Maria Wojtak, Gatunki prasowe, (Lublin : Wydawnictwo Uniwersytetu Marii Curie-Skłodowskiej, 2004), 43.

32 Irena Kamińska-Szmaj, Język polskiej lewicy. Od Wielkiego Proletariatu do końca PRL, (Wrocław : Wydawnictwo Uniwersytetu Wrocławskiego, 2017), 158-159.

33 Zarząd Główny Ligi Kobiet, „Wybory a nasze sprawy”, Kobieta i Życie, nr 2, 1957, 2.

34 Ibidem. 
Jak wspomniano, kierownictwo Ligi Kobiet na łamach periodyku przedstawiało i promowało sylwetki kandydatek do sejmu przez nie popieranych. Na łamach gazety podawano datę ich urodzenia, przynależność partyjna, wykonywany zawód. Dla wzmocnienia przekazu publikowano również ich zdjęcia. Ukazały się fotografie: Alicji Musiałowej, Marii Boguszewskiej, Heleny Jaworskiej, Jadwigi Prawdzicowej, Zofii Wasilkowej, Eugenii Krassowskiej, Zofii Stypułkowskiej, Zofii Skołozdro, Jadwigi Kowal, Marii Maniakówny, Michaliny Tatarkówny-Majkowskiej, Gertrudy Bulisiewiczowej ${ }^{35}$. Sylwetki opisano też w numerze informującym, które $z$ kobiet dostały się do sejmu. W styczniowym wydaniu „Kobiety i Życia” podsumowano kampanię wyborcza. Pisano, że była niełatwa, a kandydaci FJN napotykali trudności w trakcie działań kampanijnych: „Niełatwa była to kampania. Przeciw Frontowi Jedności, przeciw interesom narodu rozpętała się kampania wstecznictwa. Nawoływanie do bojkotu wyborów, o skreślenia czołowych kandydatów i w ogóle wszystkich partyjnych. Tę kampanię reakcji naród przekreślił zdecydowanie"36.

W przytoczonym fragmencie artykułu występowała klasyczna strategia propagandowa. $Z$ jednej strony korzyścią był sam wybór członków FJN na posłów, z drugiej zaś nastąpiła hiperbolizacja zagrożeń, gdyby do władzy doszli przeciwnicy polityczni. W retoryce powyborczej pojawiały się charakterystyczne dla lewicowego autorytaryzmu obraźliwe określenia wrogów politycznych: „wstecznictwo, reakcja”37.

\section{Kwestie przemilczane}

Na łamach „Kobiety i Życia” nie znalazły się odniesienia do poparcia przez ówczesnego Prymasa Polski kardynała Stefana Wyszyńskiego i Episkopat przemian politycznych zapoczątkowanych w październiku 1956 r. Symptomatycznym symbolem poparcia polityki partii było wystosowanie ogłoszenia duszpasterskiego nawołujacego wiernych do uczestnictwa w wyborach:

Niedziela 20 jest w Polsce dniem powszechnych wyborów do Sejmu. Katolicy-obywatele maja w tym dniu spełnić swój obywatelski obowiązek sumienia wzięcia udziału w głosowaniu. Duchowieństwo ka-

35 „Kandyduja”, Kobieta i Życie, nr 3, 1957, 4.

36 „Po wyborach”, Kobieta i Życie, nr 4, 1957, 2.

37 Irena Kamińska-Szmaj, Język polskiej lewicy, 158-159. 
tolickie tak pokieruje nabożeństwami, by wszyscy wierni mogli bez przeszkód wypełnić swoje obowiązki religijne i obowiąek wyborów ${ }^{38}$.

Nigdy później hierarchowie kościelni tak otwarcie nie nawoływali do uczestnictwa w wyborach. Takie działania spowodowane były nadzieja na dalszą poprawę położenia Kościoła w systemie politycznym PRL.

\section{Zakończenie}

Prezentacja zebranego materiału skłoniła do wysnucia następujacych wniosków. Redakcja czasopisma „Kobieta i Życie” była rozbudowana pod względem formalnym i strukturalnym. Dzięki szerokiej ofercie prasowej miało znaczne grono odbiorczyń $z$ różnych grup społecznych. Ważnymi elementami procesu komunikacyjnego na łamach periodyku było stosowanie narzędzi medialnych takich jak tematyzacja treści czy konsekwentnej tematycznie agendy medialnej. O atrakcyjności oferty prasowej formułowanej przez redakcję „Kobiety i Życia” świadczyło posługiwanie się w przekazach medialnych zróżnicowanymi formami gatunkowymi. Wyborczy przekaz medialny dopełniony został przedrukami przemówień i listów otwartych aktywistek Ligi Kobiet.

\section{Bibliografia}

\section{Artykuly w prasie:}

Kalbarczyk, Ryszard. „Kto czyta pismo kobiece?”, Nasze Problemy, t. 3, 1979, 35-40.

„Kandyduja”, Kobieta i Życie, nr 3, 1957, 4.

„Krótko o ważnych sprawach - w kraju”, Kobieta i Życie, nr 29, 1956, 2.

„Krótko o ważnych sprawach. W Kraju”, Kobieta i Życie, nr 1, 1957, 2.

Musiałówna, Alicja, „Czego oczekujemy od Sejmu”, Kobieta i Życie, nr 75, 1956, 2.

„Po wyborach”, Kobieta i Życie, nr 4, 1957, 2.

Putrament, Jerzy. „Nie zmarnujcie tej szansy”, Kobieta i Życie, nr 2, 1956, 2. Wolf, Anna. „W Sejmie”, Kobieta i Życie, nr 32, 1956, 3.

\footnotetext{
38 Antoni Dudek, Zbigniew Zblewski, Utopia nad Wisła. Historia Peerelu, (Warszawa-Bielsko-Biała : Wydawnictwo Naukowe PWN, 2008), 150.
} 
Zarząd Główny Ligi Kobiet, „Wybory a nasze sprawy”, Kobieta i Życie, nr 2, 1957, 2.

\section{Źródła internetowe:}

Stowarzyszenie Instytut Studiów Kobiecych, [Dostęp: 9.09.2019]. Dostępny w World Wide Web: <http://www.isk.bialystok.pl/>.

\section{Wydawnictwa encyklopedyczne:}

Kantyka, Zbigniew. „Politologia (I)”, w: Wojciech Sokół, Marek Żmigrodzki (red.), Encyklopedia politologii, t. 1: Pojęcia, teorie i metody, (Warszawa : Wydawnictwo Wolters Kluwer, 2016), 481. ISBN 978-83-264-9401-7.

\section{Opracowania:}

Adamski, Franciszek. Modele małżeństwa i rodziny a kultura masowa, (Warszawa : PWN, 1970).

Antoszewski, Andrzej. Współczesne teorie demokracji, (Warszawa : Wydawnictwo Sejmowe, 2016). ISBN 978-83-7666-469-9.

Bajka, Zbigniew. Czytelnictwo prasy w Polsce $w 1986$ roku, (Kraków : RSW Prasa-Ksiażka-Ruch, 1987).

Buhler, Pierre. Anatomia oszustwa. Polska w czasach komunizmu, (Warszawa : Wydawnictwo Narodowego Centrum Kultury, 2014). ISBN 978-837982-020-7.

Dajnowicz, Małgorzata, Miodowski, Adam (red.). Polityka i politycy $w$ prasie XX i XXI wieku, (Białystok: Wydawnictwo Humanica, 2016). ISBN 97883-946177-0-7.

Dajnowicz, Małgorzata, Miodowski, Adam (red.). Polityka i politycy $w$ prasie XX i XXI wieku. Polityka w prasie kobiecej, (Białystok: Wydawnictwo Uniwersytetu w Białymstoku, 2019). ISBN 978-83-7431-561-6.

Dajnowicz, Małgorzata, Miodowski, Adam (red.). Polityka i politycy $w$ prasie XX i XXI wieku. Prasa organizacji politycznych, (Białystok: Wydawnictwo Humanica, 2017). ISBN 978-83-946177-3-8.

Dudek, Antoni, Zblewski, Zbigniew. Utopia nad Wisła. Historia Peerelu, (Warszawa-Bielsko-Biała : Wydawnictwo Naukowe PWN, 2008). ISBN 97883-7446-667-7. 
Eisler, Jerzy. Czterdzieści pięć lat, które wstrzasnęty Polska. Historia polityczna PRL, (Warszawa : Wydawnictwo Czerwone i Czarne, 2018). ISBN 978-83-7700-316-9.

Eisler, Jerzy. „Wybory w PRL: wprowadzenie do zagadnienia”, w: Sebastian Ligarski, Michał Siedziako (red.), Wybory i referenda $w$ PRL, (Szczecin : Instytut Pamięci Narodowej, 2014), 9-22. ISBN 978-83-61336-26-6.

Fiske, John. Wprowadzenie do badań nad komunikowaniem, (Wrocław : Wydawnictwo Uniwersytetu we Wrocławiu, 1999). ISBN 83-7249-019-8. Kamińska-Szmaj, Irena. Język polskiej lewicy. Od Wielkiego Proletariatu do końca PRL, (Wrocław : Wydawnictwo Uniwersytetu Wrocławskiego, 2017). ISBN 978-83-229-3588-0.

Lisowska-Magdziarz, Małgorzata. Analiza tekstu $w$ dyskursie medialnym, (Kraków : Wydawnictwo Uniwersytetu Jagiellońskiego, 2006). ISBN 97883-233-2276-4.

Markiewicz, Henryk, Romanowski, Andrzej. Skrzydlate słowa, (Warszawa : Wydawnictwo PWN, 1990). ISBN 83-06-01141-4.

Nowak, Ewa. Ustanawianie agendy politycznej przez media. Efekt newsa $w$ Polsce, (Lublin : Wydawnictwo Uniwersytetu Marii Curie-Skłodowskiej, 2014). ISBN 978-83-7784-511-0.

Pisarek, Walery. O mediach i języku, (Kraków : Wydawnictwo Universitas, 2007). ISBN 978-83-242-0678-0.

Pisarek, Walery. Polskie słowa sztandarowe i ich publiczność, (Kraków : Wydawnictwo Universitas, 2002). ISBN 83-242-0003-7.

Pisarek, Walery. Wstep do nauki o komunikowaniu, (Warszawa : Wydawnictwa Akademickie i Profesjonalne, 2008). ISBN 978-83-60501-14-6.

Sokól, Zofia. Prasa kobieca w Polsce w latach 1944-1995, (Rzeszów : Wydawnictwo Wyższej Szkoły Humanistycznej, 1998). ISBN 83-87288-46-2.

Szczepańska, Sabina. „Kobieta - zwierzę polityczne?”, w: Małgorzata Radkiewicz (red.), Gender - kultura - społeczeństwo, (Kraków : Wydawnictwo Rabit, 2002), 91-100. ISBN 83-88668-44-7.

Wojtak, Maria. Gatunki prasowe, (Lublin : Wydawnictwo Uniwersytetu Marii Curie-Skłodowskiej, 2004). ISBN 83-227-2255-9.

Wolny-Zmorzyński, Kazimierz, Kaliszewski, Andrzej, Furman, Wojciech. Gatunki dziennikarskie. Teoria, praktyka, język, (Warszawa: Wydawnictwo WSIP, 2006). ISBN 978-83-60501-01-6. 


\section{Artykuły w czasopismach naukowych:}

Adamski, Franciszek. „Konflikty małżeńskie i ich źródła na łamach "Kobiety i Życia”", Zeszyty Prasoznawcze, t. 1, 1978, 23-32. ISSN 0555-0025.

Konarska, Krystyna, Łoś, Maria, Łoskot, Małgorzata. „Czasopisma kobiece czy rodzinne?”, Więź, t. 9, 1965, 55-73. ISSN 0511-9405.

Luhmann, Niklas. „Öffentliche Metnung”, Politische Vierteljahresschrift, vol. 11, 1975, 2-28. ISSN 0032-3470.

Maliszewska, Anna. „Wzory wychowawcze w prasie kobiecej (szkoła i rodzina jako instytucje wychowawcze)", Zeszyty Prasoznawcze, t. 4, 1975, 15-25. ISSN 0555-0025.

Nowak, Ewa. „Teoria agenda-setting a nowe media”, Studia Medioznawcze, $\mathrm{nr}$ 3, 2016, 11-13. ISSN 2451-1617.

Sokół, Zofia. „Kobieta i Życie (1946-2002)”, Studia Bibliologiczne Akademii Świętokrzyskiej, t. 9, 2005, 63-93. ISSN $1231-0972$.

Sokól, Zofia. „Transformacja czasopism kobiecych w Polsce (1989-1997)”, Rocznik Historii Prasy Polskiej, t. 1, 1998, 193-201. ISSN 1509-1074.

Sokół, Zofia. „Wizerunki kobiet na łamach tygodnika "Kobieta i Życie» w latach 1946-2002", Rocznik Prasoznawczy, t. 6, 2012, 11-36. ISSN 18975496.

Sokół, Zofia. „Wzór osobowy kobiety i model rodziny propagowany na łamach prasy kobiecej w latach 1945-1990", w: Weronika Chańska, Danuta Ulicka (red.), Polskie oblicza feminizmu, (Warszawa : Wydawnictwo Uniwersytetu Warszawskiego, 2000), 66-85. ISBN 83-87608-02-5. 